\title{
Beethoven Returns to Bonn: Origins, Belonging and Misuse in Mauricio Kagel's Ludwig van (1969)
}

\author{
Elaine Fitz Gibbon
}

»Beethoven und Goethe blieben die Embleme des kunstliebenden Deutschlands, für jede politische Richtung unantastbar und ebenso als Chiffren manipulierbar« (Klüppelholz 2001, 25-26).

"Beethoven and Goethe remained the emblems of art-loving Germany: untouchable for every political persuasion, and likewise, as ciphers, just as easily manipulated."

The year 2020 brought with it much more than collective attempts to process what we thought were the uniquely tumultuous 2010s. In addition to causing the deaths of over two million people worldwide, the Covid-19 pandemic has further exposed the extraordinary inequities of U.S.-American society, forcing a longoverdue reckoning with the entrenched racism that suffuses every aspect of American life. Within the realm of classical music, institutions have begun conversations about the ways in which BIPOC, and in particular Black Americans, have been systematically excluded as performers, audience members, administrators and composers: a stark contrast with the manner in which 2020 was anticipated by those same institutions before the pandemic began. Prior to the outbreak of the novel coronavirus, they looked to 2020 with eager anticipation, provoking a flurry of activity around a singular individual: Ludwig van Beethoven. For on December $16^{\text {th }}$ of that year, Beethoven turned 250.

The banners went up early. In 2019 on Instagram, Beethoven accounts like @bthvn_2020, the "official account of the Beethoven Anniversary Year," sprang up. The Twitter hashtags \#beethoven2020 and \#beethoven250 were (more or less) trending. Prior to the spread of the virus, passengers flying in and out of Chicago's O'Hare airport found themselves confronted with a huge banner that featured an iconic image of Beethoven's brooding face, an advertisement for the Chicago Symphony Orchestra's upcoming complete cycle

Current Musicology 107 (Fall 2020)

(02020 Fitz Gibbon. This is an open access article distributed under the terms of the Creative Commons-Attribution-Non- 


\section{Current Musicology}

of Beethoven symphonies. In early January 2020, after discovering this fact, members of the group Citizens for Beethoven [Bürger für Beethoven] in Bonn, Germany began advocating for a similarly prominent banner announcing the celebratory year at the Konrad Adenauer Cologne/Bonn airport, arguing in a petition to the airport that "it certainly seems strange that Beethoven is more visible in Chicago's airport-where he never was-than it is in that of his birth city. We hope that this will soon be rectified." Furthermore, the significance of Beethoven's birthday was of course reflected in the programming of classical music institutions around the world, where Beethoven cycles were being marketed with greater prominence than usual, despite this repertoire's dominance on the concert stage during the ostensibly "non-Beethoven" years.

In reaction to this onslaught of Beethoven celebrations, there were provocative counter-calls for anti-memorializations. In December 2019 musicologist Andrea Moore, in an article for the Chicago Tribune, provocatively proposed the institution of a year-long Beethoven silence, arguing for a "cooperative, worldwide, yearlong moratorium on live performances of [Beethoven's] music" (2019). And when the dubious theory of Beethoven's "Moorish" roots regained support on Twitter, Germanist and musicologist Kira Thurman (2020) asked the Twitterverse to consider why fixation upon the racial identity of such a canonical figure remains so strong, while efforts to expand the canon to include Black musicians and composers working throughout Europe (such as George Polgreen Bridgetower, the virtuoso violinist and composer to whom Beethoven initially dedicated his Kreuzer sonata) are ignored. ${ }^{3}$ What these radical poles of over- and under-saturation make clear is that Beethoven is not a neutral topic.

In many ways, he never was. Beethoven has long possessed a kind of symbolic function for the world of classical music. As Lydia Goehr (1992) famously demonstrated, Beethoven's death coincided with the advent of the work concept, and since then, the composer has been endowed with the extraordinarily ambivalent honor of representing the entire canon of Western classical music.

But Beethoven has occupied this position for over two centuries, and we in 2020 are not the first to be confronted with the frustrations attendant upon oversaturation and fetishization. Considering how radically our lives have changed in recent months, comparisons with previous celebratory years might currently seem like a laughable proposition. And yet an examination of past Beethoven anniversaries-specifically, the 1970 bicentenary and Mauricio Kagel's film Ludwig van, a sardonic meditation on such memorializations-will, 
I argue, shed light on our own strange predicament. The controversy surrounding Kagel's film and the 1970 bicentenary serves as a reminder that, as creatures of habit, we readily cling to that which is familiar in the face of global travesties, often to the detriment of already marginalized groups and individuals.

\section{Uses, Misuses and Memorials}

In 1970, Beethoven celebrated his $200^{\text {th }}$ birthday. And just as 2019 featured many an anticipatory, Beethoven-freighted program, 1969 also saw amped-up Beethoven marketing campaigns. In postwar Europe, various German-speaking countries, including Austria, Switzerland and West Germany, competed to produce the best and most bombastic Beethoven celebrations. Additionally, East Germany proclaimed itself to be the singular German nation to have inherited the true spirit of Beethoven. Already in 1952, at the $125^{\text {th }}$ anniversary of the composer's death, the Presidium of the GDR's National Assembly had gone so far as to declare the West German relationship with Beethoven to be one of cultural perfidy:

The American cultural barbarians and their lackeys defile Beethoven's memory in their misusage of Bonn, his birthplace, for the most pernicious debasement of the nation. These cosmopolitan attempts to subvert the great German cultural values are undertaken in Bonn in order to destroy the national consciousness of the German people. ${ }^{4}$ (Stahl 2009, 55)

It would seem that universal brotherhood of Beethoven's celebrated "Ode to Joy" can be cast away in the face of the potential "misuse" of Beethoven, all resonances of the illogic of cultural patrimony and superiority aside. ${ }^{5}$ The uncanny resemblance of this "blood and soil" language to the rhetoric of the Nazi era was not a singular occurrence that year. Nor was the indignant East German statement regarding the West and Beethoven an anomaly. Indeed, the 1952 Beethoven anniversary provoked, if anything, even more vitriolic mudslinging between East and West than the arguably more momentous 1970 bicentennial. This, however, was likely due to the timing of the 1952 memorial: it occurred only three years after the 1949 split of Germany into the two nations. The 1952 anniversary year, being one of the first major celebrations of a canonical figure of Germany's artistic culture to be celebrated by two different German states, served as an opportunity for both countries to assert the benefits of their respective ideological orientations and methods of government on an international stage. 


\title{
Current Musicology
}

Panic over the misuse of Beethoven, be it his music or image, also surfaced during the lead-up to the 1970 bicentennial. So pervasive were the anxieties that in 1969 the composer and experimental filmmaker Mauricio Raúl Kagel (commissioned by the West German state) dramatized the absurdity inherent in such accusations in his film, Ludwig van: A Report, for which he acted as author, musical arranger, actor and director. ${ }^{6}$

\author{
Click to play video \\ [please note: playback may not work in some PDF readers]
}

Figure 1: The opening scene of Ludwig van (Kagel 2006, 0:00-0:54).

The film opens with a brief shot of a man shaving and mumbling pejorative nonsense words about the Beethoven bicentenary:?

Diese Beethovenjahrerei, diese Beethoven, Bumm, Bumm, Bumm, Jahrerei, dieses Bumm Bumm, diese Beethovenbummelei, Bumms, Bummerei, diese Bummserei, diese Beethovenbummelei, Bummserei, diese Beethovenbummselei. Alle zweithausend Jahre wieder. Diese Bummserei, diese Beethovenbummelei. Rasulei, Beethovenrasulei, Schnumm, Schnumm, Bumm, Bumm, Bumm, Bumm.

This Beethoven-Year-foolery, this Beethoven-boom-boom-boom-Year-nonsense, this boom-boom, this Beethoven-dawdling, booms, boom-nonsense, this thumping around, this Beethoven-laziness, thumping nonsense, this Beethoven-thumping, every two-thousand years ${ }^{8}$ over and over again. This booming around, this Beethovendawdling. Shaving-frenzy, ${ }^{9}$ Beethoven-shaving-frenzy, schnoomm, schnoomm, boom boom boom boom. ${ }^{10}$ (Kagel 2006, 0:00-0:54)

The suffix "-erei" in German often denotes a negative situation or activity, such as: die Barberei (barbarism), die Heuchelei (hypocrisy), or die Schweinerei (mess, but more often: swinishness). However, it can also be used as an intensifier, transforming words to denote an activity taken to extremes. In this 
case, the man shaving uses the verbs "bumsen," a vernacular term for the verb "to thump" (including connotations of sex), which is here used in reference to the Fifth Symphony, with its five opening "booms." ${ }^{11}$ Additionally, the man uses the verb "bummeln," a similarly colloquial term for moseying, dilly-dallying, or generally moving slowly and aimlessly.

In other words, this unidentified individual with soap and razor has strong feelings-very strong indeed-about the upcoming celebrations. But then there's a revelation: this grumbler is in fact Beethoven himself, who, costumed in eighteenth-century dress, is then seen riding on a train into Bonn's main station. Quite an opening - the film's subsequent ninety-minute-long reflection on Beethoven's cultural legacy was not the bromide the West German officials had doubtless hoped for.

Ludwig van can be parsed into two main sections, each approximately forty-minutes long, divided by an eleven-minute interlude that occurs at the precise center of the film. The first half of Ludwig van is shot almost entirely from the perspective of "Beethoven" as the composer wanders throughout Bonn, a city significantly transformed in the 200 years since his birth. In contrast, the second half of the film is devoted to various academic, scientific, physiological, and zoological studies of the composer and his reception.

In part one, we see Beethoven return to Bonn, where onlookers steal baffled glances at the weirdly dressed outsider, who seems progressively more alienated as he strolls past stores filled to the brim with recordings of his music and iconic representations of his person. Eventually Beethoven even takes a tour of his own birth house, now a historical monument, led by a museum guide who bears an uncomfortable resemblance to Hitler. The older docent wears the same mustache and also has the same haircut as Hitler, which becomes evident when he briefly takes off his cap. The headgear prominently bears the title, "Fremdenführer" (Figure 2), rather than the term "Museumsführer" ("museum guide") and this is no accident. 


\section{Current Musicology}

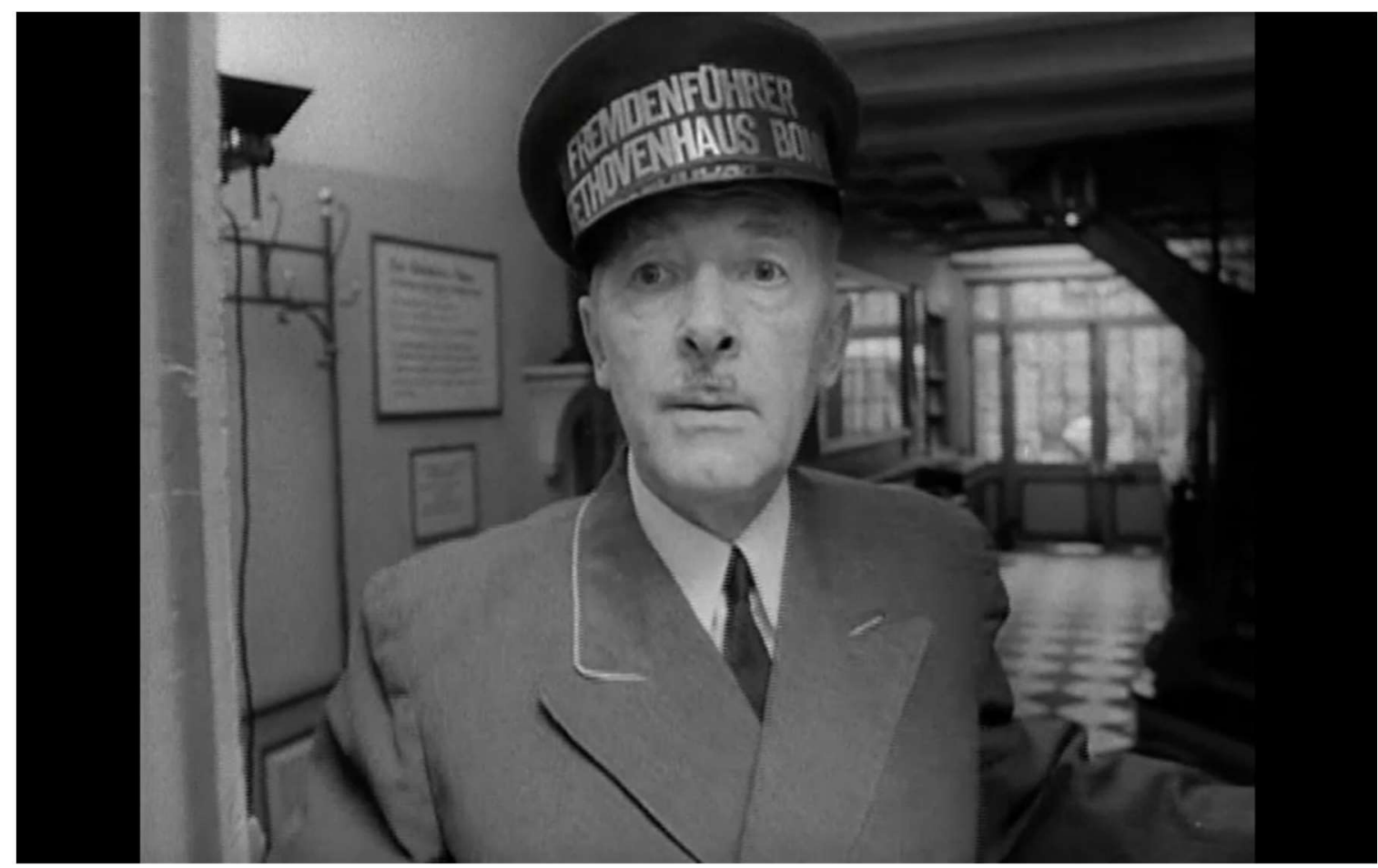

Figure 2: The "Fremdenführer."

The word "Fremdenführer*in" is commonly used in German to refer to a tour guide, for they are "leading" those who are new or unfamiliar (fremd) to the museum or location. But Kagel uses the actor's strong resemblance to Hitler here as a double entendre. The term "Fremdenführer" is also a play on Hitler's biography_for he was a native Austrian, not German-as well as on his status as a "Führer" of a collection of non-German states that the Third Reich conquered and annexed. Such an interpretation implies a rejection of responsibility for the Holocaust, using the non-German origins of the Third Reich's leader to intimate that a German-born individual could not have committed the same atrocities. This line of thinking is in keeping with that of early West German attempts to grapple with the recent German past, which tended to focus upon high-ranking members of the Nazi government tried at the Nuremburg trials, describing these individuals as pathologically evil rather than, as Adorno and Horkheimer famously argue in their Dialectic of Enlightenment (1947), products of a rational organization of society founded upon the instrumentalizing logic of Enlightenment values. As the West German president Konrad Adenauer put it in 1951: "The German people, in its overwhelming majority, abhorred the crimes perpetrated against the Jews and did not participate in these crimes" (Lewy 2017, 2). Indeed, the new West German constitution (the Basic Law, or Grundgesetz) was written in 1949 from the 
perspective that the new country must protect itself legally from the ability of political groups to seize power, thus identifying the "causes" of the Holocaust as rooted in the political might of a small group of radicalized individuals (Olick and Levy 1997, 926). In this way, in the years following the conclusion of the Second World War, as Lewy argues, "Germany tried to escape its own history. It saw itself as a nation of victims, helpless in the face of totalitarian terror and therefore incapable of opposing Nazi policies" (Lewy 2017, 2). ${ }^{12}$

The clever wordplay of Kagel's Fremdenführer, with its almost laughably absurd attempt to deny culpability through the logic of Hitler's national origin, thus references the desperate desire of postwar German society to mitigate any direct confrontation of responsibility for the atrocities committed over the course of the Nazi era. ${ }^{13}$ In placing Hitler in the position of a low-level functionary, Kagel also points to the widely known, but little discussed presence of many former Nazis in the West German government itself (Olick and Levy 1997, 925-926). When an aging Hitler leads Beethoven around a West German museum dedicated to his life and birth, it becomes clear that the ideological appropriation of Beethoven and his music by the Nazis was not just a strand in the lineage of contemporary bourgeois institutionalization and fetishization of Beethoven, but that these acts of curatorship are still presided over in 1969 by actual, aging Nazis. ${ }^{14}$

In the first half of Ludwig van, all of these increasingly surreal experiences are filmed with the shaky hand of the composer himself. And we are further inserted into Beethoven's consciousness through the soundscape of the film, which replicates a kind of deafness by exploring in certain passages what Beethoven's interior aural experience might have been. Instead of experiencing the diegetic noises of the street or tour guide, we hear a near-constant stream of Beethoven's music, but played imperfectly and out of tune, and often arranged for unusual combinations of instruments. The music is uncannily familiar, yet palpably different, much like the experience Beethoven seems to be having in twentieth-century Bonn.

\section{"With a Slight Accent": Der Internationale Frühschoppen}

Kagel is best known for his absurdist aesthetic; his collaborations with Fluxus artists like Joseph Beuys, Dieter Roth and Robert Filliou (as is the case of Ludwig van); and for the development of a kind of avant-garde musical theater he 


\section{Current Musicology}

referred to as "instrumental theater." Born in Argentina to Russian- and German-Jewish parents in 1931 and living in Cologne since 1957, Kagel can be seen as a member of what Brigid Cohen has referred to as "the avant-garde diaspora." One can recognize migration "as formative rather than incidental to [Kagel's] community bonds, ethical aspirations, and creative projects" (as Cohen has argued in regard to modernism writ large $[2012,143])$. After emigrating to Cologne in 1957 on a fellowship from the German Academic Exchange Service (DAAD), Kagel made the city his home, returning to Argentina only two times for professional reasons before his death in 2008 (Heile 2006, 12). ${ }^{15}$ Kagel was deeply enmeshed in West Germany's vibrant new music scene, and after only a couple years he spoke fluent German and taught, wrote, and published in the language as well. Despite this, Kagel was endlessly forced to inhabit the status of a cultural outsider, made explicit in the central scene of Ludwig van when Kagel performs as himself, or rather, a version of himself, in a parody of a famous West German talk show.

In this scene, a group of six men sit around a table, seen below in Figure 3 , with Kagel second from the left. They are equipped with cigarettes and wine glasses, as well as name tags that specify nation of origin.

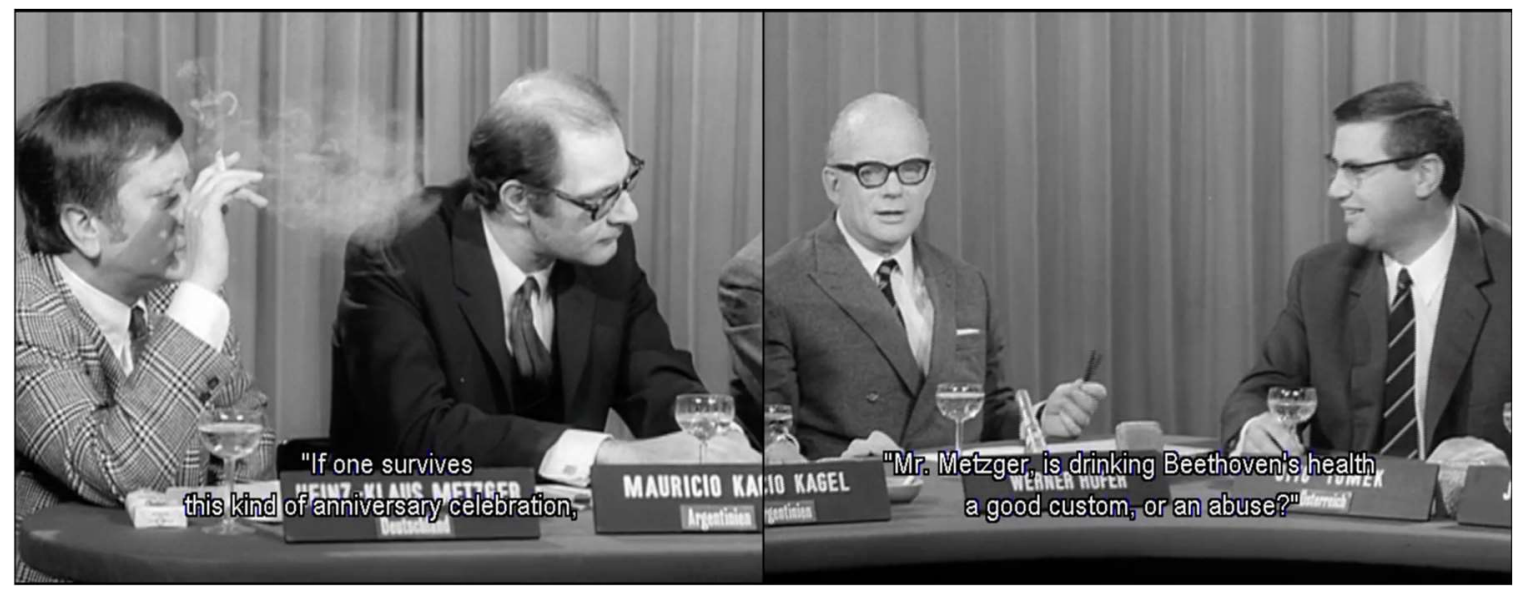

Figure 3: Two stills from the Internationaler Frühschoppen discussion.

The camera pans around the room, and we see a staged episode of the WDR's (West German Broadcasting Company) Der Internationale Frühschoppen (the International Morning Drinks Show), West Germany's first televised political talk show, which ran from 1952 until 1987 under the direction of Werner Höfer (1913-1997). Boasting a colorful crowd of "exotic," "international" perspectives broadcast live at 11:30am Sunday mornings, Höfer's show was known for taking its titular job seriously. ${ }^{16}$ White wine was served to guests-almost exclusively male-to fuel the mingling of international perspectives, a mingling that on 
more than a few occasions swiftly turned into raucous shouting and the utterance of prejudiced or paternalist opinions. ${ }^{17}$ Moderated by the gregarious and charismatic Höfer (himself a known former Nazi), the International Morning Drinks Show received its international character from the series of guests invited each week. ${ }^{18}$ Indeed, this fact is boasted of in the show's famous introductory announcement, which was always intoned in the same manner by Egon Hoegen, who is also featured in this role at the conclusion of Ludwig van's Frühschoppen scene. Hoegen would welcome audiences to the news program with the following greeting: "Good afternoon ladies and gentlemen. Here again is the International Morning Drinks Show, with six journalists from five countries." 19

Click to play video

Figure 4: Hoegen's Introduction for the Internationaler Frühschoppen. ${ }^{20}$

To German audiences in the late 1960s or 70s, this show would have been immediately recognizable: in 1970 Der Internationale Frühschoppen had a viewership of about ten million, or one quarter of the then-adult population of West Germany. ${ }^{21}$ But regardless of an audience member's viewing habits, the show would also have been easily recognized due to the fact that Kagel was able to engage Höfer himself, as well as all of the guests seated at the table around him, to play themselves in Kagel's parody ${ }^{22}$ This singularly male roster included the film and music producer Victor Staub (who also acted as producer for the film itself); the music critic Otto Tomek (who at the time was employed by the WDR); the well-known musicologist Heinz-Klaus Metzger; the film-maker and future director of the WDR music-television department José Montes-Baquer; and Kagel himself. ${ }^{23}$ One might remark, however, that the "international" quality 


\section{Current Musicology}

of the show is highly questionable. The five countries labeled on each nameplate are: Switzerland, Austria, Germany, Spain, and Argentina. But by the time of filming, Kagel had been living in Cologne for twelve years, while the representative from Spain, the film director Montes-Baquer, had emigrated to West Germany in 1959. Only just barely qualifying as international, each guest is scripted to perform an exaggerated foreignness by speaking in highly stereotyped accents, while discussing the universality of Beethoven and debating whether the composer is "misused in the world."

This staged conversation parodying the Internationaler Frühschoppen is prefaced by a three-minute "behind-the-scenes" preview, in which the six participants debate what they might do in the upcoming minutes of filming. At the opening of the sketch, we witness Höfer's condescending and outright insulting treatment of Kagel and his film, and even attempts by the other panelists to stick up for him in response, as we are brought into the pre-show discussion in media(s) res. The film cuts immediately to the Morning Drinks scene from a 45-second-long interlude that features an older gentleman in a suit who looks directly in the camera as he strokes his face, neck, and ears with increasing intensity, accompanied by a brass and percussion ensemble that, present in the preceding scene, continues their performance of a transcription of Beethoven's Piano Sonata No. 12 in A-flat major, op. 26. This dynamic cut is all the more startling because of the presence of spoken language in the pre-show discussion, the first instance of speech in the film since an early part of Beethoven's tour of the Beethoven House, a full twenty-two minutes earlier. The sudden presence of speaking individuals on screen, with audio- and image-tracks aligned, thus makes for an emphatic transition that is further disorienting due to the immediately perceptible fact that we have been patched in mid-conversation. Suddenly privy to a discussion that appears to be preparatory and thus not meant for public consumption, the viewer is prompted to trust the documentary work of the camera capturing these seemingly organic moments of conversation.

The scene opens with Höfer's suggestion that they simply leave things be as they are: "We're leaving all that, and the evening after the broadcast we'll have a real discussion. We!" to which Kagel inquires, "And what about my film?" (Kagel 2006, 45:38-45:51). ${ }^{24}$ Höfer's opening declarative statement and Kagel's response suggest that Höfer, true to character, is taking advantage of his authoritative position as director of the talk show, using this position of power to disregard Kagel's intentions for his project, the film for which Höfer was engaged. Later in the exchange, Höfer refers to Kagel in the third person, preferring to direct his protests against Kagel's artistic desires towards the other 
members of the panel rather than address Kagel himself. Höfer complains of Kagel, "Under no circumstances is he... I can see it, he's an amateur, but he's chock-full of ideas... But you can't reduce him to three sentences" (2006, 45:5946:11). ${ }^{25}$ This brash attitude is in keeping with Höfer's public personality, for he was known for speaking his mind without regard to civility, and for his aggressive dominance of the conversation. In fact, the show was even popularly referred to as the "Werner-Höfer Show" (Reufsteck and Niggemeier 2005, 593). Confirming the viewer's expectations of Höfer's behavior, these opening minutes invite the viewer to understand this interaction as having truly taken place, increasing the level of trust in the documentary role of the camera. In what follows, however, this trust is eroded, leading to a nagging suspicion that these real-life individuals are in fact playing themselves in a dramatized version of reality.

During this pre-show discussion, the six men eventually agree to film their roundtable conversation after the manner of the International Morning Drinks Show, taking its concept "ad absurdum," as Kagel suggests to the group. However, Kagel's suggestion to stage the show as such is expressed already after we have seen the men sitting in the typical setting for the show itself, and Kagel even utters the idea as a woman moves around the table to pour white wine in each participant's glass. The entirety of this seemingly spontaneous, preparatory scene is thereby exposed as artificial and pre-scripted, putting the viewer on their guard for the exaggerated performances to come. And indeed, this suspicion is confirmed in the staged Morning Drinks Show scene, as we view precisely what was agreed upon by the six men in the brief preview-scene: a Beethovensaturated, at times emotionally excited discussion. Throughout the panel, Höfer asks each guest for their "international" perspective on his opening series of questions:

So, does Beethoven really belong to the world? If so, then might a German Beethovenfan actually ask the world: What has the world Beethoven to thank for? What does it owe him? Or: what bad things has the world done to Beethoven? (Kagel 2006, 47:41$47: 57)^{26}$ 


\section{Current Musicology}

\section{Click to play video}

Figure 5: Höfer's opening questions (Kagel 2006, 47:41-47:57).

Turning first to Heinz-Klaus Metzger, Höfer asks, "Mr. Metzger, is there such a thing as Beethoven abuse [einen mißbrauchten Beethoven]?"27 To this, Metzger responds in caricatured fashion with an excessively Adornian and academic response, reading from a paper that he has prepared in advance. As he reads, the others look around the room at each other, clearly baffled by the content of Metzger's monologue and also slightly bemused by his intense focus and obtuse refusal to be stirred from his own serene obliviousness.

Soon, Höfer requests Kagel's international perspective. In this exchange, Kagel is spoken to by Höfer with even greater exaggerated condescension than the others, as Höfer asks exoticizing and purportedly ethnographic questions about musical culture in Argentina:

HÖFER: Mauricio Kagel: if we weren't sitting now in Cologne or Bonn or somewhere in Beethoven territory, but in Buenos Aires... that's your capital? ${ }^{28}$

KAGEL: Yes.

HÖFER: ... and went out into the streets. Of ten people, would more of them know Beethoven, or more of them Kagel? (Kagel 2006, 51:40-51:59) ${ }^{29}$ 


\section{Click to play video}

Figure 6: Höfer questions Kagel (Kagel 2006, 51:40-51:59).

Demonstrating the difficulty of responding politely to such facetious questions, Kagel affirms that of course it is Beethoven's name that residents of Buenos Aires would know, not Kagel's. Here, this biographically revised Kagel also performs with an exaggerated accent and makes a number of grammatical mistakes that are corrected by an interrupting voiceover. ${ }^{30}$ The voice speaks in a castigating tone, yet is strangely familiar: in fact, it represents the inner-voice of Kagel himself, staging for the viewer the self-lacerating inner-monologue of a nonnative German speaker, thus further accentuating this performance of Kagel's foreignness. No other guests are subject to this corrective voiceover despite the exaggeration of each individual's accent. After affirming that he is less famous than Beethoven in Buenos Aires, Kagel goes on to discuss the political nature of musical performance in the context of postwar migration, and it is here that the self-correcting voiceover appears.

Naja, selbstverständlich Beethoven. Nicht wahr, Beethoven hat immer ein Schild getragen an der linke Westentasche [self-correcting voice over (SVO): an der linken] und da stand drauf: Made in Germany. Und das ist ein ganz wichtigen Punkt [SVO: wichtiger Punkt]. Ich habe es eigentlich als Südamerikaner sehr gut beobachten können, daß die Liebe zu Deutschland oder die unglückliche Mißliebe zu Deutschland sich immer in der Liebe zu deutscher Musik umgeschlagen hat [SVO: niedergeschlagen hat]. Das bedeutet, wie oft deutsche Musik während des Krieges gespielt worden ist, hängte damit [SVO: zusammen] mit der politischen Situation. Und es ist nicht zu vergessen, daß Fritz Busch, Erich Kleiber, die deutschen Emigranten, in Argentinien sehr tätig waren. Und man machte deutsche Musik eben als politische Demonstration. 


\section{Current Musicology}

Look, obviously Beethoven. You know, Beethoven always had a sign fastened to his left vest pocket... [SVO: adjective declension] ${ }^{31}$... and it said: Made in Germany. And that's a really important point [SVO: adjective declension]. As a South American I was actually well able to observe that love of Germany or an unfortunate dislike of Germany always turned into love of German music [SVO: correcting separable-prefix verb]. That means that how often German music was played during the war depended [SVO: missing separable prefix] on the political situation. And one mustn't forget that Fritz Busch and Erich Kleiber, German émigrés, were very active in Argentina. And one did German music as a sort of political demonstration (2006, 51:59-53:00).

Click to play video

Figure 7: Kagel and the Self-Correcting Voiceover (Kagel 2006, 51:59-53:00).

Identifying himself as South American, Kagel points to his outsider status as a productive position from which to view the reception of Beethoven as historically contingent and politically inflected. But in this talk show so dedicated to international perspectives, any more complicated identity shaped by the complexities of migration or diaspora is erased by the national identifier placed on each nameplate. The performed exaggerations of cultural difference demonstrate the sharpened tensions produced by the premise of the International Morning Drinks Show, which simultaneously invites interest in the perspective of the international guest and fetishizes the difference that they represent. In turn, these performances of national identity reify the difference that the show, with its titular gesture towards pluralism, purported to mediate. ${ }^{32}$ Within this nationally bounded context, Kagel inhabits a version of himself that he had already relinquished, performing an exoticized figure that had been (and continued to be) constructed of him in the Western European and U.S.American press (Spiel 1970; Henken 1988; "Kagel trompe la mort" 1991). ${ }^{33}$ Often 
identified in press coverage as an "Argentinian composer living in Cologne," in the film, Kagel satirizes that essentialization by delivering precisely the image that many native-born Germans desired to see of him: an Argentinian, conversant in German, providing for the listening German public a digestible soundbite on his home country. Here, Kagel plays to liberal fantasies of immigrants observing their newly adopted societies and making critical interjections that ultimately, through the plurality of voices and perspectives, leads to the betterment of those societies. Demonstrating the painful experience of making linguistic errors in a foreign tongue, Kagel performs an outsider perspective that, while superficially appreciated, is, as Höfer demonstrates, easily discarded as unknowing, particularly when that perspective happens to be expressed with a few grammatical errors. In this scene, the idealized cycle of feedback and societal transformation through a society invested in pluralism is demonstrated to possess a broken circuit- linguistic difference proving too high a hurdle for the locals in "Beethoven Territory" to jump in the name of peaceful, postwar democratic pluralism. Through this performance, Kagel unmasks the superficial nature of such liberal ideology, demonstrating the underlying fetishization of foreignness upon which the International Morning Drinks Show is based.

\section{Skull Shape and Skin Tone: Beethoven's Last Living Relative}

The central Frühschoppen sketch serves as a pivotal moment in Ludwig van, as the film shifts its focus from documenting Beethoven's twentieth-century return to Bonn to a more distanced and fragmented series of scenes that showcase and parody specific examples of Beethoven reception history. The Frühschoppen conversation delivers a potent discussion on how origins can be used to delineate lines of ownership and belonging, stemming from a fanatic obsession with genealogy. And these ideas continue to resonate in the short sketch that begins immediately following the conclusion of the Internationaler Frühschoppen discussion, whose ending is signaled by the calm outro ("That, dear ladies and gentlemen, was our 'Frühschoppen' ['Morning Drinks Show'] with guests from five countries") provided by Egon Hoegen (which audiences would have recognized from the real show, again in large part because Hoegen was engaged to play this part as well). ${ }^{34}$ In the three-minute scene that follows upon the Frühschoppen's heels (Kagel 2006, 55:50-59:06), Kagel brings together two seemingly unrelated news reports from early 1969-one relating to the bourgeoning the idea that Beethoven was Black, and the other documenting a 


\section{Current Musicology}

potential living relative of Beethoven's-entwining their ideas and events to create a fictionalized scene that ultimately demonstrates their shared ideological commitment to genealogical fetishization and ultimately, xenophobia.

After the conclusion of the staged International Morning Drinks show, the film suddenly cuts to an empty field, where a man stands before a horse and plow and speaks in an animated fashion to three men who, equipped with cameras and microphones, appear to be newspeople (Figure 8). In the background, the large cylindrical constructions of an oil refinery loom over the comparatively small human figures and affirm that the scene is set in North Rhine-Westphalia's industrial Ruhr Valley, the home of Bonn.

Click to play video

Figure 8: Mr. Poll, Beethoven’s “last living descendent” (Kagel 2006, 55:50-57:05).

As we approach the man-named Mr. Poll (possessing the maiden name of Beethoven's grandmother) - the topic of his monologue becomes clear, for he proclaims, "I am the last and only living descendant of Ludwig van Beethoven, and on his mother's side." Holding court before the camera crew, Mr. Poll delivers a rambling history of the Beethoven family, during which he asserts their "ancient Flemish lineage" and ascribes to Beethoven's grandfather an "iron resolve and great energy," thanks to which "he finally achieved the exceptional position of Kapellmeister" of the Bonn Hofkapelle (2006, 55:50-56:37).$^{35}$ Soon, however, this recounting of purportedly familial anecdotes transforms into a defensive assertion of his legitimate status as a Beethoven ancestor:

I greatly admire Ludwig van Beethoven, I like listening to his records and we have got many documents and papers from his ancestors that prove that I really am the last descendant; all those others who claim to be his descendants are wrong. And I always 
carry a bust of Ludwig van Beethoven with me. You can see the similarity, when I put our heads close together. But proof of a much deeper similarity is given by the rather dark color of this bust. This dark shading comes from the fact that there was also rather dark blood flowing in Beethoven, via some mulattoes from the West Indies (2006, $57: 05-58: 00){ }^{36}$

Click to play video

Figure 9: Phrenology rears its ugly head (Kagel 2006, 57:05-59:06).

Swerving swiftly from a professed aesthetic enjoyment of Beethoven's music to an argument for ancestral relation based on phrenology, Kagel illuminates with a single gesture the ideological underpinnings of Poll's idée fixe, the necessary truth of his familial relation to Beethoven. At this point the camera suddenly begins to sway back and forth, and Mr. Poll recedes slowly in the distance: the person filming has joined the three newsmen as they retreat in what appears to be disgust. This retreat is not, however, particularly successful, for Mr. Poll's voice continues to be heard, even after the film has cut to a new scene, as his anxious claims for legitimacy interrupt the public television moderator who is featured next.

Just over a half-century ago, interest in the theory that Beethoven was Black blossomed in the United States. As Michael Broyles documented in his study of the complicated reception of Beethoven in the United States, the Black British composer Samuel Coleridge-Taylor is thought to have been the first to publicly voice the idea in an interview published in 1907 (Broyles 2011, 269). ${ }^{37}$ According to his biographer Berwick Sayers, Coleridge-Taylor based the theory on Beethoven's friendship with George Bridgetower and on representations of Beethoven's person, in which Coleridge-Taylor saw traits he recognized to be 


\section{Current Musicology}

phenotypically Black. ${ }^{38}$ In the 1960 s, with the progress of the civil rights movement and the fight against nearly a century of Jim Crow laws, the theory gained popularity. In May of 1963, in an interview for Playboy Magazine, Malcolm X grouped Beethoven with the likes of Jesus Christ and Columbus, as he discussed what he referred to as a "history-whitening process" and powerfully demonstrated the ways in which Black history and culture and the contributions of Black individuals have been written out of Western history (Broyles 2011, 267268) ${ }^{39}$ After the publication of this interview, the phrase "Beethoven was Black" spread rapidly throughout the United States and could be found on posters and heard on the radio. ${ }^{40}$ Eventually, West Germany caught word, and on 17 February 1969, Brigitte Zander-Spahn, a foreign correspondent for the Süddeutsche Zeitung working in San Francisco, published a dismissive and racist summary of the phenomenon under the title, "Was Beethoven a Mestee? 'Black America' Harnesses the Great Composer for Their Own Purposes" (ZanderSpahn 1969). ${ }^{41}$

In the Beethoven frenzy of 1969 , as Bonn was waiting in anticipation of the Beethoven House's completed renovations in time for the composer's bicentennial, the inhabitants of this new seat of the West German government were invested in a different origin theory. Just ten days prior to the Süddeutsche's report from America, Marion Schreiber of Die Zeit published an article on a newly discovered, potential living relative of Beethoven's, Peter Köwerich: "Bonn, the capital of the Federal Republic and Beethoven city, in addition to having a Beethoven high school, a Beethoven hall, a Beethoven house and a Beethoven pharmacy, can now also boast of having a Beethoven relative" (Schreiber 1969). ${ }^{42}$ As Schreiber goes on to describe in her report, some researchers had long thought Köwerich to be a potential relative of Beethoven through his great-grandfather, who was related to the brother of Beethoven's mother, thus leading the director of Bonn's city archive to present Mr. Köwerich on the television news program Bonner Rundschau as the "only living relative of the great Master in Germany" (Schreiber 1969). ${ }^{43}$ As proof, this local news show provided the "persuasive" evidence that Köwerich, a vintner, displayed a portrait and a bust of Beethoven in his wine bar.

While working on his film, Kagel saved contemporary news reports about Beethoven and his upcoming bicentennial. ${ }^{44}$ Braiding the content of two of them together to form the material that makes up the "Beethoven-heir" scene, Kagel subtly thematizes these articles' shared fixation upon claims of ownership based in genealogy, despite the geographical and presumed cultural distance between the United States and West Germany in 1969. In staging the desperate 
pleas for attention by a demonstrably mad man (who uses any "evidence" he can grasp to gain notoriety), Kagel utters a powerful critique of prevailing obsessions with Beethoven's origin, demonstrating the fundamentally xenophobic roots of these preoccupations.

In Ludwig van, the cultural figure of Beethoven, two hundred years after his birth, has gained enough power to even drive a man mad. This madness derives from a fixation upon lineage, not the aesthetic power of Beethoven's musical works, with the material remnants of popular celebrity, like the busts or mass-produced portraits that Mr. Poll carries with him as "proof," used to assert genealogical relation. The fetishized othering of Beethoven-his purported "dark blood," to use Poll's language-is yet another trait that Mr. Poll proudly instrumentalizes to attest to his own Beethovenian blood, while contemporary newspaper articles like Zander-Spahn's embraced racist and paternalist language to refer to African Americans, indignant at the suggestion that Beethoven might have had non-white, non-European ancestors, and resorting to a racially-based "logic" made far too familiar by the Nazis.

In fact, Mr. Poll's monologue bears great similarity to the opening paragraphs of a popular Nazi-era Beethoven biography by the German art historian-turned-musicologist Walter Riezler (1878-1965). The biography, monolithically titled Beethoven, went through a number of publications, even seeing six new editions over an eight-year period, a period that also coincided with nearly the entire duration of the Second World War. This massively popular biography was first published in 1936 by the Swiss publishing house Atlantis and by 1944 was in its sixth edition. This printing even featured a brief preface by Wilhelm Furtwängler, in which the internationally recognized conductor-who represented the pride of German symphonic might during the Nazi era-extolls the biography's merits by speaking of the pride that Beethoven brings to the German people (Riezler 1944). ${ }^{45}$ Indeed, Riezler's Beethoven was apparently so popular that a new, "partially revised and significantly expanded" edition was published in 1951 (most likely in anticipation of the 1952 Beethoven anniversary). In the following years, further new editions were released, including two more during the decade of the 1960s. ${ }^{46}$

In the opening paragraphs of Beethoven, Riezler narrates in only slightly more elaborated detail Mr. Poll's story, quoted above. Additionally, after recounting the history of Beethoven's family up until Ludwig van Beethoven's birth, Riezler includes a short parenthetical: "(According to his blood, he [Beethoven] is one sixteenth Walloon-one of his great-great grandmothers had a maiden name of Gouffau-three sixteenths Germanic Fleming, and twelve 


\section{Current Musicology}

sixteenths German)" $(1944,19){ }^{47}$ It must be noted, however, that Riezler's text cannot be classified as a stereotypical Nazi biography (like those by Ludwig Schiedermair and Werner Korte), as Lewis Lockwood recently outlined in his study of the history of Beethoven biographical writings (Lockwood 2020). ${ }^{48}$ In 1933, not long after the Nazis took power, Riezler himself was forced into retirement from his position as director of the Städtisches Museum Stettin (today the National Museum in Szczecin, Poland) due to "non-conformity with the ethnic (völkisch) understanding of art" ["Nichtübereinstimmung mit der völkischen Kunstauffassung"], and unsuccessfully attempted to emigrate from the country (Wendland 1999, 551). It was during this period-the duration of the Third Reich - that Riezler turned to the study of music history and published Beethoven, whose first edition was printed by Atlantis in both Berlin and Zurich. With its focus upon Beethoven's family history, Beethoven might in fact be seen as an attempt to push back against Nazi ideological control, while capitulating to the censors through the inclusion of a parenthetical note in accordance with early twentieth-century illogic of ethnic nationalism. Regardless, however, of Riezler's intentions, the biography remained indubitably marked by the historical conditions of its writing and its fetishism of Beethoven's genealogy cannot, as Kagel demonstrates through Mr. Poll's monologue, be dismissed as harmless.

Leaning upon a biography that, a product of the year 1936, reports the percentages of nationally defined blood coursing through Beethoven's veins in order to claim his familial heritage-even if it be through Beethoven's alcoholic grandmother Johanna Maria Poll, as Mr. Poll notes in his genealogical sketch of the composer-it comes as no surprise that Mr. Poll's monologue eventually ends in comparisons of skull shape. ${ }^{49}$ The defensive use of Beethoven's national origins to delineate an exclusive "Beethoven territory" was demonstrated and critiqued in the Frühschoppen conversation. And in the scene that follows upon its heels-as Mr. Poll unites orientalist, phrenologist, and fetishizing tendencies (themselves borrowed from the Nazis) to prove his genealogical claim of ownership to this fecund symbol of German culture-echoes of Höfer's question, "Is Beethoven misused in the world?" can still be clearly heard.

Responding to the explicit racism of West German journalistic reaction to calls to recognize Beethoven as Black in the United Sates, Kagel demonstrates the tensions that arise when claims for cultural or national ownership of an historical figure are made based on arguments of race. This is not to deny the great liberatory potential that the claim of Beethoven's Black heritage has possessed for the Black community, and continues to possess-as was witnessed on Twitter 
(and other social media platforms) in the summer of 2020-in the face of relentless systemic racism in the United States and elsewhere. However, as scholars such as Kira Thurman (2020) and Josephine Wright (1980) have demonstrated in reference to George Bridgetower, the continued fixation on the genealogy of canonical individuals like Beethoven replicates a history of erasure of those Black individuals who, over the course of the writing of Western European history, have been purposefully forgotten due to their racial identity. ${ }^{50}$ In this scene, which features a man driven to mad desperation by an ideal of genealogical relation to Beethoven, Kagel illuminates what the film Ludwig van demonstrates to be an ultimately destructive tendency: the obsessive fascination with and mythologization of a singular individual, to the point of the complete saturation of a cultural landscape.

As the film progresses, the viewer is confronted with further examples of Beethoven reception history, taken to absurd extremes in the form of brief sketches, all of which explore and question the definition and ramifications of "Beethoven misuse" and the often-accompanying obsession with the composer's origins. The film concludes with one of the longest scenes in the second part of Ludwig van, lasting more than eight minutes, which features video footage of a variety of zoo animals, including an elephant defecating. These images are paired with the sounds of the WDR men's chorus rehearsing passages from the "Ode to Joy" from Beethoven's Ninth Symphony and the "Freedom Chorus" from Beethoven's opera, Fidelio. It was predictable perhaps that this scene provoked audience members at the film's world premiere at the Wiener Festwochen on 28 May 1970 to shout epithets including "filth!" and "mindless crap!" (Brunner 1970, 368). ${ }^{51}$ This seemingly disjunct Beethoven-animal pairing-and the outrage it provoked-point effectively to the great chasm that formed over the course of the nineteenth century between Beethoven-the complicated, messy man who experienced the common realities of daily life-and the mythological deity who authored works that, throughout the past two centuries, have been found to express the transcendental, utopian hopes and desires of humanity. As Abigail Fine argues regarding the discourse around late style in Beethoven, it is vital that we "approach this discourse with fresh eyes only after it has been disentangled form the relics, legends, and curios that enchanted Beethoven's fans," for as she demonstrates, "the foundational discourse on lateness crystallized in part around celebrity culture" (Fine 2020, 146). Kagel's Ludwig van is an exercise in precisely such an attempt at disentanglement. 


\section{Current Musicology}

(Mis)using Beethoven in the Twenty-first Century

To whom does Beethoven belong? To the world or to those in "Beethoven territory," that "Beethovenraum" to which Höfer casually refers? What is "Beethoven territory," and how far does it geographically extend? Is Beethoven "missbraucht" (misused), and if so, how and by whom? Ludwig van raises these questions and many more in querying the fetishistic celebration of Beethoven's 200 -year reign. In so doing, Kagel makes clear that the stakes of this ritual revolve around precisely such nationalist, patrimonial questions. "Misuse," even if figured within a critique of conservative, capitalist institutional structures, always presupposes an originary, exclusionary, and often defensive "use," as the East German presidium took pains to demonstrate to the "lackeys" and "cultural barbarians" of the West in 1952. As Ludwig van progresses, it becomes clear that the missing "Beethoven" in the film's title is no accident: the "van," or "from," points to the collective obsession with Beethoven's origin and cultural belonging, and how these concerns emanate from the figurehead of the canon to all of those active in the world of classical music. The question of origins is not secondary here. In fact, it makes up the title of the film, and it presages the vigorous "debate" over the "misuse" of Beethoven that Kagel stages at the center of Ludwig van.

Fifty years later, even in a world ravaged by a global pandemic, not much seems to have changed. And with members of the U.S. government (and many others around the globe) spouting increasingly xenophobic rhetoric, we have witnessed an increase in blunt expressions of the same cultural patrimony. Judging by the Beethoven-mania that has in turn sparked calls for a year-long Beethoven ban, and the recently revived interest in the composer's genealogy, Beethoven fanaticism appears not to have diminished one bit in the past halfcentury. In fact, it may have even increased, making one wonder just what kind of shock Beethoven would experience were he to return to Bonn again this year. Ludwig van is simultaneously a kind of love letter to a celebrated composer and a devastating critique of the institutions that have facilitated the continued exploitation of his music and image. Perhaps it is a misuse of Beethoven, as Kagel suggests in Ludwig van, to love Beethoven to the point of blanketing out one's entire soundscape..$^{52}$ As we participate, or abstain from participating, in this celebratory year, we might ask ourselves what relation these acts of memorialization have with the oft-bemoaned "death" of classical music in the United States. Scott Burnham (1995), for example, has argued that the instinctual rush to defend canonical figures such as Beethoven from the perceived taint of association with non-canonical composers, or even more contemporary music, 
is ultimately destructive to the health of the musical world. The perennial fear would seem to be that those whom Beethoven continues to influence-the living composers amongst us-might somehow affect the Beethoven we know and love through the acoustic intimacy of concert programming. The irony that such defenses belie a presumption of great fragility on the part of these canonical figures would seem to be lost on their steadfast defenders. However, we owe it, as Burnham writes, "to the well-being of our musical ecology" to recognize "the cost of such defense mechanisms," for in so doing, "we may even find that Beethoven no longer needs to be defended" (1995, xix). ${ }^{53}$

The public conversations regarding racism in the U.S.-American classical music industry that have occurred in the wake of George Floyd's murder in June 2020 have brought hope to some that works by historical and contemporary Black composers will finally enjoy more than tokenized presence in (virtual) concert halls. Let us hope that this progress is not fleeting, as composer Jessie Montgomery warned in a recent New York Times article (Barone 2020). For as Kagel makes clear in his now 52-year-old film, what we, and Beethoven, require is not yet another year of singularly Beethoven-based programming, but instead, a year of Beethoven dialogue: a kind of meta-Beethoven celebration to engage with the messy, productive history of his ideological (mis)use. Rather than covering our ears with Beethoven wallpaper, let us open them to the 250 years of Beethoven reception history: a resonant conversation that might prove to be more aurally and even politically productive than listening to the familiar strains of the "Ode to Joy" one more time.

\section{Acknowledgements}

I would like to express my great thanks to the editor of Current Musicology, Callum Blackmore, for the opportunity to present my work in this journal and for his and the anonymous readers' generous and productive feedback. Heartfelt thanks are also due to Winter $\&$ Winter and IFAGE Filmproduktion for their generosity in allowing me to reproduce images and clips from Ludwig van in this article. Earlier versions of the material that makes up this article were presented at the winter chapter meeting of the New England Chapter of the AMS, as well as at the 2020 annual meeting of the AMS and I am grateful not only to have had these opportunities to present my work in these fora, but also for the lively, encouraging, and generative feedback I received. I am also grateful for the support of Professors Anne C. Shreffler, Carol J. Oja, Carolyn Abbate, and Kate van Orden, who have seen the idea for this article move through various stages and who helped shape it into what it is today. Additionally, I am indebted to the members of Carol Oja's dissertation group and the inimitably supportive friends and members of my department-including Samantha Jones, Sarah Koval, Cana McGhee, and Uri Schreter-as well as to Lucy Fitz Gibbon and Ryan MacEvoy McCullough, whose love of the anamorphic absurd and willingness to indulge me in all things Kagel have 


\section{Current Musicology}

been particularly meaningful this past year. Finally, I would like to express my enormous gratitude to Scott Burnham for the generosity of his spirit, humor, and mentorship, and for whose encouragement over these past years I cannot thank him enough.

Notes

${ }^{1}$ All translations are my own, unless otherwise stated.

2 "Es wirkt schon merkwürdig, dass von Beethoven am Flughafen in Chicago mehr zu sehen ist als bei unserem Flughafen für seine Geburtsstadt. Wir hoffen, dass sich das bald ändert." So wrote the President of the group, Stephan Eisel, in a letter to the executive board of the Cologne/Bonn airport:

https://www.buergerfuerbeethoven.de/start/2020/Intro/news/Am-internationalen-

Flughafern-in-Chicago-wird-prominent_8475.html? $\mathrm{xz}=0 \& \mathrm{cc}=1 \& \mathrm{sd}=1 \& \mathrm{ci}=8475$

(accessed 25 January 2020).

${ }^{3}$ See Thurman (2020), as well as Thurman's conversation with violist and co-founder of Castle of Our Skins, Ashleigh Gordon, on Jonathan van Ness's podcast "Getting Curious," from 7 July 2020, "Are We Hearing A Crescendo of Anti-Racism in Classical Music?" (https://www.earwolf.com/episode/are-we-hearing-a-crescendo-of-anti-racism-in-classicalmusic-with-dr-kira-thurman-and-ashleigh-gordon/). For an account of the history of this theory in the United States in the twentieth century, see Broyles (2011) and de Lerma (1990). And for an excellent and detailed account of Bridgetower's life and years in London, see Wright (1980).

4 "Die amerikanischen Kulturbarbaren und ihre Lakaien schänden das Andenken Beethovens, indem sie Bonn, seine Geburtsstadt, für die verderblichste nationale Entwürdigung mißbrauchen. Von Bonn aus werden die kosmopolitischen Zersetzungsversuche der großen deutschen Kulturwerte unternommen, um das Nationalbewußtsein des deutschen Volkes zu zerstören.” Originally published by the Zentralkomitee der Sozialistischen Einheitspartei Deutschlands under the title "Zum 125. Todestag Ludwig van Beethovens am 26. März 1952" in the GDR music journal Musik und Gesellschaft. That the GDR refuses to even name West Germany-choosing rather to refer to them as the "lackeys" of the United States-is in keeping with the GDR's general rhetoric at that time. The East German government often accused the West of being, while nominally independent, in truth a colony of the U.S., and spread rumors that the U.S. was using West Germany in order to prepare for a Third World War. See Stahl (2009) and Denning (1996). Finally, see Rehding (2009) for discussion of Beethoven's music as "monumental" and politically symbolic, and in particular Rehding's epilogue on the performances of Beethoven's Ninth Symphony in celebration of the fall of the Berlin Wall (Rehding 2009).

${ }^{5}$ For a detailed, though particularly dated in regard to the analysis of Cold War politics, history of Beethoven's presence and use in German politics, see Denning (1996). Additionally, for an art historical perspective on the long history of fascination for Beethoven in the visual realm, see Comini (1987), as well as Fine (2020) for a more focused study of Beethoven's life and death masks.

${ }^{6} \mathrm{Ludwig}$ van is publicly available at the following site:

https://ubu.com/film/kagel_ludwig.html. 
The timings referenced throughout this article refer to the video found on this website, as they also coincide with those of the DVD, which is available for purchase from the Winter \& Winter Verlag.

${ }^{7}$ This man is played by Stefan Wewerka (1928-2013), a German architect, designer and artist who was active in the Cologne avant-garde arts scene during this period.

${ }^{8}$ That "two-thousand years" is stated here is never explained over the course of the film.

9 "Rasulei" is a nonsense word; however, it bears resemblance to two words pertinent to this character's speech: the noun, "Raserei" and the verb, "rasieren." The noun "die Raserei" means frenzy, fury or furor, indicating the character's (who soon will be revealed to "be" Beethoven) disdain for the obsessive furor around celebrations of the upcoming Beethoven year in West Germany. This neologism also possesses association with the verb "rasieren," meaning to shave, which activity the character is performing during the entirety of this scene.

${ }^{10}$ The German transcription is taken from the subtitles provided in the film. The English subtitled version does not provide subtitles for this scene, as the text consists in large part of portmanteaus and nonsense words. The translation is my own and I thus take responsibility for any and all inaccuracies that might be present. All other transcriptions of passages from Ludwig van, in both German and English, are transcribed from the film's subtitles unless otherwise noted.

${ }^{11}$ See Scott Burnham's remarks regarding the ubiquity of "the amputated opening motive" of the Fifth Symphony in popular culture "as both sound-bite and talisman" (Burnham 2000, 289).

${ }^{12}$ See also Olick and Levy's (1997) insightful analysis of German constructions of victimhood as a product of both "instrumental rationality," as well as an "inability to understand their own implication in what had happened" (Olick and Levy 1997, 928). The authors go on to note, "there is widespread evidence that many German people-often obsessed with their own victimhood-could not even imagine why anyone should think that collective guilt was appropriate" (1997, 928). In discussing the West German government's response to the idea of collective guilt during the Adenauer regime, Olick and Levy argue, "One reason for denying collective guilt is that it was strategically a disadvantage; another is that it was an unacceptable proposition for an expertly equivocating and evasive population" $(1997,928)$.

${ }^{13}$ As Lewy notes, it was not only West Germans who felt such a desire: the West German portrayal of their citizenry as passive victims of Nazi totalitarianism bears a keen resemblance to GDR rhetoric regarding who was to blame for the Nazi rise to power. He notes, "[The West German perspective] showed an interesting similarity to the official position of the East German communist regime, which regarded German fascism as a special form of monopoly capitalism that had subjugated the German people" (Lewy 2017, 2). Additionally, see Dennis's analysis of Beethoven in East and West German politics (Dennis 1996, 175-203), as well as the previously discussed rhetoric of the East during the 1952 commemoration of the $125^{\text {th }}$ anniversary of Beethoven's death, for which Stahl also provides excellent analysis in her second chapter, "Beethoven in beiden deutschen Staaten" (Stahl 2009, 52-105). 


\section{Current Musicology}

${ }^{14}$ For discussion of the tensions of the classical music establishment after the so-called "Zero Hour" in West Germany, specifically in the realm of opera, emblematic as that institution is of bourgeois culture and values, see Richmond Pollock (2019).

${ }^{15}$ Heile's language is unclear. While the text indicates without hesitation that Kagel returned to Argentina twice, his endnote first cites personal correspondence with Kagel from 2002, while going on to note that Kagel traveled to Buenos Aires in 2006 for a celebration of his life and works. Heile does not clarify whether that 2006 trip is included in the number he notes in the text, but it is my assumption that it does (Heile 2006, 12n8).

${ }^{16}$ When the streaming time of the Internationaler Frühschoppen was moved to $12 \mathrm{pm}$ in 1970, protests broke out, predominantly from women, who were no longer able to view the show due to the necessity of performing domestic duties at noontime in preparation for the mid-day meal (Reufsteck and Niggemeier 2005, 594). The name of the show is translated more or less literally: the adjective "früh" means "early" in German and "der Schoppen" is a noun meaning a glass containing a quarter or a half-liter of wine or beer. "Frühschoppen" can be translated as "morning pint" and can also be used in the sense of a social meeting, often connoting a Sunday morning get-together for a drink, and in traditionally Catholic areas such as Bavaria or Austria in particular, after church.

17 The Fernsehlexikon takes care to note that this wine was a Riesling Spätlese named "Meikämmerer Heiligenberg," which was also served in the WDR cantina (Reufsteck and Niggemeier 2005).

${ }^{18}$ In 1969 Höfer was not only celebrating his twenty-fifth year as director of the Internationaler Frühschoppen, he had also just been named head of the WDR's recently created Drittes Fernsehprogramm (in 1964), the educational channel of the WDR's public programming. In 1972 he would go on to become the television director of the WDR itself. Fifteen years later, however, Höfer resigned from his post a week after Der Spiegel published a detailed account of Höfer's active Nazi past (which general fact was known already) on 14 December 1987. The article focused in particular on Höfer's publication of a text for the Nazi publication, the 12Uhr-Blatt, that celebrated the murder of a young, virtuoso pianist, Karlrobert Kreiten (19161943), who was executed by the Nazis for State-critical utterances ("Feindbegünstigung und Wehrkraftzersetzung"), despite pleas for clemency from as powerful individuals as Wilhelm Furtwängler (Wieser 1987). This fact was actually made public by a GDR official (Albert Norden, leader of the SED's Committee for Agitation and Propaganda) fifteen years earlier in 1962 and that year Höfer's explanation that his text had been dramatically edited by Nazi officials and that it was not written with direct reference to Kreiten (for he is not named explicitly in the article) was stomached relatively easily by the West German public. However, in 1987 attitudes had changed and Höfer's actions and attempt to distance himself from responsibility for the article could no longer be ignored. See Olick and Levy's discussion of changing attitudes towards the Nazi past in West Germany over the course of the 1960s and 70s (Olick and Levy 1997, 928).

19 "Guten Tag meine sehr verehrten Damen und Herren. Hier ist wieder der Internationale Frühschoppen mit sechs Journalisten aus fünf Ländern.”

${ }^{20}$ See https://www.youtube.com/watch?v=WgjGKsi8rZ4 for a (German-language) 
${ }^{21}$ See a report on the program published in the New York Times in 1970: "His [Höfer's] program, 'Internationaler Frühschoppen,' is West Germany's longest-lived television program. It enjoys a solid audience of about 10 million or, one quarter of the adult population of Germany" (Binder 1970). Binder does not specify whether this population is specific to West Germany or both East and West Germany, but the number is in accordance with West Germany's population.

${ }^{22}$ These five invited guests were not regular guests of the actual Frühschoppen show; however, they were all active members of the West German classical music scene, and in the case of Heinz-Klaus Metzger in particular, very prominent individuals within that community. All were active in West German public media, including press, radio and television.

${ }^{23}$ Montes-Baquer acted as the executive producer of Ludwig van as well. Like Kagel, MontesBaquer traveled to Germany on a fellowship from the DAAD, where he studied musicology in Munich. Montes-Baquer went on to work at the BBC, the Bayerischer Rundfunk, CBS, and beginning in 1967, the WDR. There is an odd discrepancy in the spelling of Montes-Baquer's name in the program book for the 2006 digitally remastered version of Ludwig van; here, his name is spelled: "Montes-Bacquer." In the film, Montes-Baquer is referred to only as "José Montes."

24 "HÖFER: Wir lassen das Ganze und am Abend nach der Sendung machen wir wirklich eine Diskussion. Wir! KAGEL: Und was ist mit meinem Film?"

25 “HÖFER: Er ist unter keinen Umständen... das merk' ich, er ist doch Amateur und ist bis zur Halskrause akkumuliert mit Ideen... Er ist doch nicht auf drei Sätze zu bringen.” One might note that these are words that themselves might be turned against Höfer, given his loquacious and domineering tendencies.

26 "HÖFER: Ja, Beethoven gehört der eigentlich der Welt? Wenn ja, dann dürfte ein deutscher Beethoven-Fan eigentlich die Welt doch fragen: Was hat die Welt Beethoven zu danken? Was ist sie ihm schuldig geblieben? Oder: Was hat die Welt an Beethoven Schlimmes getan? Herr Metzger, gibt es so etwas wie einen mißbrauchten Beethoven?"

27 "HÖFER: Herr Metzger, gibt es so etwas wie einen mißbrauchten Beethoven?"

${ }^{28}$ Again, these transcriptions have been taken from the film's subtitles, though here with a small emendation: I hear Höfer use the third person possessive pronoun when confirming that Buenos Aires is the capital of Argentina, which would also be more in accordance with Höfer's condescending tone, for in referring to Buenos Aires as "Kagel's" capital city, Höfer further accentuates Kagel's foreignness.

29 "HÖFER: Mauricio Kagel: Wenn wir jetzt nicht in Köln oder Bonn oder wo auch immer im Beethoven-Raume säßen, sondern in Buenos Aires... das ist Ihre Hauptstadt? KAGEL: Ja. HÖFER: ... und wir gingen auf die Straße. Kennen von zehn Leuten mehr Leute Beethoven oder mehr Leute Kagel?"

${ }^{30}$ While Kagel did speak with a slight accent, he exaggerates it here for this performance, using grammatical errors to draw particular attention to this othering. Evidence of Kagel's manner of speaking at the time can be observed in documentary footage of film production for other works produced during that period and even that year. Seen in August 2018 at the Paul Sacher Foundation, collection Mauricio Kagel. 


\section{Current Musicology}

31 The grammatical mistakes made by Kagel are difficult to translate into English, for they consist of incorrect adjective declensions or a missing prefix in a separable-prefix verb. I have marked the presence of the voice over (not indicated in the film's English subtitles) to communicate its presence.

${ }^{32}$ In fact, as Verheyen (2010) demonstrates, the International Morning Drinks Show was a part of an attempt to support West Germany's nascent democracy in the years following the "Zero Hour" through the encouragement of both formal and informal discussion, based on an American model of democratic public discourse. In the years following the end of the Second World War, "discussion" developed into a genre of communication, which was modeled in didactic fashion by television programs like Höfer's International Morning Drinks Show (Verheyen 2010, 151-153).

${ }^{33}$ See press coverage of Kagel and his work in German, French, as well as U.S.-American journalism throughout his career. For instance, in Hilde Spiel's review of Ludwig van for the Frankfurter Allgemeine Zeitung, she writes, "Mauricio Kagel, 1931 in Buenos Aires geboren, seit 1957 in Europa" (Spiel 1970), and in an article published in an article regarding protests in response to Kagel being awarded the 1998 Erasmus Prize in the same paper, Kagel is referred to as "[der] in Köln lebende Argentinier" (dpa 1997). Similar language is used in the FAZ press release announcing that Kagel was awarded the eleventh Prix Maurice Ravel in 1999: "Der aus Argentinien stammende Komponist Mauricio Kagel erhält den 11. Prix Maurice Ravel” (dpa 1999). For U.S.-American examples see Anthony Tommasini's reference to Kagel as "the Argentine composer long resident in Germany" in a review of Kagel's Entführung im Konzertsaal (1998-99) for the New York Times (Tommasini 2000) or John Henken's description of Kagel in a review for the Los Angeles Times: "The 56-year-old Argentine has built an unclassifiable career as composer, performer, dramatist, film maker and teacher-in the last capacity significantly as professor new new music theater at the Cologne Musikhochschule since 1974" (Henken 1988). Similar descriptions are also found in the French press. See, for instance, an article published in Le Monde that discusses Kagel's activities as part of a festival in Caen, whose full title reads: "Kagel trompe la mort: Argentin fixé en Allemagne, champion du théâtre musical, Mauricio Kagel est toujours déconcertant” ("Kagel trompe la mort” 1991). 34 "Hoegen: Das, meine sehr verehrten Damen und Herren, war der 'Internationale Frühschoppen' mit Gästen aus fünf Ländern. Heute zum Thema: Wird Beethoven mißbraucht? Teilnehmer waren der Argentinier Mauricio Kagel, der Österreicher Otto Tomek, der Schweizer Victor Staub, der Spanier José Montes, der Deutsche Heinz-Klaus Metzger und Werner Höfer als Gastgeber."

35 "Herr PolL: Ich bin der einzig und letzte lebende Nachfahre Ludwig van Beethovens und zwar mütterlicherseits. Die Beethovens entstammen einem alten flämischen Geschlecht, die in den Dörfern in der Umgebung der alten Universitätsstadt Löwen beheimatet waren. Louis van Beethoven, der Großvater Ludwig van Beethovens, war der erste, der ins Rheinland ausgewandert ist und zwar nach Bonn. In seiner Jugend hat er Chormusik studiert. Als er nach Bonn kam, wurde er mit 21 Jahren als Bassist bei der kurfürstlichen Kapelle angestellt. Durch eisernen Fleiß und große Energie brachte er es bis zu der ausgezeichneten Stellung eines Kapellmeisters. Er war verheiratet mit Johanna Maria Poll. Nebenbei betrieb er einen kleinen Weinhandel. Das war wohl auch der Grund, daß sich seine Frau dem Trunke ergab, wohl aus 
Gram über die Kinder, die vor Johann van Beethoven, dem einzigen Sohn, der übrig geblieben war, gestorben waren. In ihren letzten Lebensjahren wurde sie in Köln in einem Kloster unter Aufsicht gestellt."

36 "HERR POLL: Ich bewundere Ludwig van Beethoven sehr, ich höre gerne seine Schallplatten und von seinen Ahnen haben wir viele Dokumente und Papiere bekommen, mit denen ich nachweisen kann, daß ich wirklich der letzte Nachkomme Ludwig van Beethovens sind [sic]; alle anderen, die sich als seien Nachkommen ausgeben, sind falsch. Ich trage auch stets eine Büste Ludwig van Beethovens bei mir. Sie sehen die Ähnlichkeit, wenn ich unsere Köpfe ein bißchen zusammenhalte. Aber einen Beweis einer noch viel größeren Ähnlichkeit soll Ihnen diese etwas dunkel getönte Büste liefern. Diese dunkle Tönung liegt daher, daß auch in dem Blut Ludwig van Beethovens etwas dunkles Blut geflossen ist und zwar durch einige Mulatten aus Westindien. Hier sehen Sie auch noch eine helle Büste, die den Beweis erbringen soll, daß ich wirklich Ludwig van Beethovens Nachkomme bin. Und hier sehen Sie auch noch eine alte Schalmei, die ist aus der Besitz Ludwig van Beethovens als ein weiterer Beweis, daß ich wirklich sein Nachkomme bin. Ich verstehe gar nicht, warum die Leute alle zweifeln, daß ich nicht der Nachkomme Ludwig van Beethovens bin. Ich kann das doch hier durch Dokumente und viele Bilder beweisen. Hier, da sehen Sie, diese Alben voll Familienfotos. Eine ganze Ahnengalerie! Hier bitte, überzeugen Sie sich doch selbst. Und auch hier, hier sehen Sie noch mehr Fotos, noch mehr Andenken an die Familie Beethovens. Und hier, da sehen Sie, alles voll... Und ich versteh' das gar nicht, dass man mir nicht zumutet, dass ich der Nachkomme Ludwig van Beethovens mütterlicherseits bin. Ich versteh gar nicht, dass man mir immer bezweifelt, dass ich wirklich der einzige und letzte Nachkomme mütterlicherseits..."

${ }^{37}$ Chapter 10 is devoted to this subject: “Beethoven was Black?': Why Does It Matter?” (Broyles 2011, 167-291). See as well de Lerma (1990).

${ }^{38}$ Sayers reports, "He [Coleridge-Taylor] returned to the theory that Beethoven had coloured blood in his veins. The supposition, he thought, was supported by the great composer's type of features and many little points in his character, as well as by his friendship for Bridgewater, the mulatto violinist” (Sayers 1915, 203).

39 "He [Malcolm X] gave a controversial interview that appeared in the May 1963 issue of Playboy. In it he asserted that Western history as written by Western historians reflected a 'history-whitening process,' in which black accomplishments were either left out or blacks who succeeded 'had gotten whitened' in the historical record. He cited a long list of Western historical figures who were black, including Jesus Christ, Columbus, and Beethoven" (Broyles 2011, 267-268).

40 "Sometime in 1968 or 1969, Doug Cass, a disc jockey at KDIA, the top-rated soul station in San Francisco, began to recite 'Beethoven was black' constantly between recordings, almost as a mantra. In reaction, mail poured in from all over the country, from clergy, from supportive blacks, from outraged whites, and from scholars" (Broyles 2011, 273).

${ }^{41}$ The German title reads, "War Beethoven Mischling? Das 'schwarze Amerika' spannt den großen Komponisten für seine Zwecke ein.” In the title, as well as the brief report, ZanderSpahn uses mocking language that communicates great disdain for the phenomenon, and for Black Americans, generally. 


\section{Current Musicology}

42 "Bonn, die Bundeshaupt- und Beethovenstadt, kann neben einem Beethoven-Gymnasium, einer Beethoven-Halle, einem Beethoven-Haus und einer Beethoven-Drogerie neuerdings auch einen Beethoven-Nachfahren aufweisen.”

43 "Sie präsentierte Herrn Köwerich aus Köwerich als 'einzigen in Deutschland noch lebenden Verwandten des großen Meisters."

${ }^{44}$ See Holtsträter's argument regarding the effect of collecting on Kagel's compositional practices and specifically Holtsträter's discussion of the preparatory work for Ludwig van $(2010,133)$.

${ }^{45}$ In fact, Riezler was a doctoral student of Wilhelm Furtwängler's father, Adolf Furtwängler, at the University of Munich and served as Wilhelm Furtwängler's private pupil for both music and Classical languages at the turn of the twentieth century (Wendland 1999, 550-551). See Roger Allen's recent monograph on Furtwängler for a detailed account of Furtwängler's complicated relationship to and history with the Nazi party and state, as well as his brief discussion of Riezler and Furtwängler's preface to the book in which he emphasizes the "Germanness" of Beethoven (Allen 2018, 145). Furtwängler writes, "In Beethoven there is a spiritual force unique in German music, and by no other composer has the power and greatness of German feeling and character been more directly expressed" (quoted in: Allen 2018, 145).

${ }^{46}$ This biography was also well received in English translation (Riezler 1938) and has been cited throughout English-language Beethoven scholarship, including, to name only a few, in publications by Lewis Lockwood (1992, 2013), Maynard Solomon (1977), and Scott Burnham (1995).

${ }^{47}$ Riezler's German reads as follows: “(Dem Blute nach ist er zu 1 Sechzehntel Wallone-eine seiner Ururgroßmütter war eine geborene Gouffau—zu 3 Sechzehntel germanischer Flame, zu 12 Sechzehntel Deutscher)" (Riezler 1944, 19).

${ }^{48}$ Lockwood focuses upon biographies that adhered to Nazi ideology and discusses the Nazi tendency to suppress any biographical detail of Beethoven's life that did not fit nicely into party doctrines (Lockwood 2020,103). This perhaps accounts for the absence of Riezler from Lockwood's study, despite the biography's great popularity in both English- and German speaking contexts over the course of the twentieth century. The reception history of Riezler's Beethoven and the book's fascinating entanglements in Beethoven reception history, both popular and scholarly, in German-speaking lands, the U.K., and the United States, is deserving of its own dedicated study.

${ }^{49}$ While it has not yet been confirmed whether or not Kagel was in possession of a copy of this biography, due to its extraordinary popularity and widespread presence-particularly in the years between the founding of West Germany and the making of Ludwig van, during which time the biography went through three further editions (nos. 7-9)-it stands to reason that Kagel was aware of the text and might have made use of it in this scene. Regardless, Mr. Poll's allusions to phrenology and fascination with Beethoven's blood are themselves strong enough to call to mind the strange and insidious world of Nazi ideologies of race and genetics.

${ }^{50}$ See works of Black German Studies scholarship such as Mazón and Steingröver (2005); Honeck, Klimke, and Kuhlmann (2013); and Lennox (2016), in addition to the scholarship of Kira Thurman, including Thurman (2019). 
51 “Ein Aufschrei des Entsetzens begleitete die Uraufführung seines Films 'Ludwig van' im Wiener Künstlerhaus. Mehrere tausend Jahre abendländischer Geistesgeschichte seien in diesen hundert Minuten verächtliche gemacht, heilige Traditionen beschmutzt, ewig gültige Werte besudelt worden: 'Schweinerei' und 'hirnlose Scheiße' tönte es Kagel aus vielen Kehlen entgegen. Wo es um Beethoven geht, findet eben auch die Wiener Gemütlichkeit einmal ein Ende" (Brunner 1970, 368). Brunner's review is singular in its positive, and quite insightful, reading of Kagel's film. Contemporaneous reviews by prominent music and cultural critics published in the Frankfurter Allgemeine Zeitung and the Süddeutsche Zeitung by Hilde Spiel and Joachim Kaiser, respectively, were in contrast quite frank in their condemnation of the film as blasphemous.

${ }^{52}$ Perhaps Ludwig van's most well-known scene is the so-called "music room," which is featured in the first half of the film as part of Beethoven's tour of his own birth house. In this scene (Kagel 2006, 25:34-34:25) the viewer finds herself in a room plastered from floor to ceiling with a collage of Beethoven scores. Not only are the walls, floor, and ceiling covered with scores, so are all of the furniture and domestic objects, such as a mirror, framed picture, music stand, votive candle, and even the white keys of an upright piano. As the camera moves around the room, focusing on certain objects, the soundtrack is entrained to the visual image: we hear what we see, resulting in a marvelously chaotic acoustic experience. The room was designed by Kagel's wife, the visual artist Ursula Burghardt (1928-2008) and also formed the basis of Kagel's chamber music work, Ludwig van: Hommage von Beethoven (Kagel 1969), whose score consists of reproductions of images from the film's Beethoven House music room.

53 "I want to believe that the tradition that has accumulated in the wake of Beethoven's music is not simply the unwitting dupe of ideological prejudice; I want to believe that the values of the heroic style are truly of value. And yet, the time has come-not to disown these values, surely-but to discern the way in which we have become invested in defending them, to discover the cost of such defense mechanisms to the well-being of our musical ecology. We may even find that Beethoven no longer needs to be defended" (Burnham 1995, xix).

References

Allen, Roger. 2018. Wilhelm Furtwängler: Art and the Politics of the Unpolitical. Woodbridge: The Boydell Press.

Barone, Joshua. 2020. “Orchestras are Rushing to Add Black Composers. Will it Last?” The New York Times (print), 2 October.

Binder, David. 1970. "Weekly TV Discussion of News Drawing 10 Million in Germany." The New York Times (print), 4 November.

Broyles, Michael. 2011. Beethoven in America. Bloomington: Indiana University Press.

Brunner, Gerhard. 1970. “Mauricio Kagel-ein Wiener Störenfried.” Melos 37, no. 9: 367368.

Burnham, Scott. 1995. Beethoven Hero. Princeton: Princeton University Press.

2000. "The Four Ages of Beethoven: critical reception and the canonic composer." Ed. Glenn Stanley. The Cambridge Companion to Beethoven. Cambridge: Cambridge University Press: 272-291. 


\section{Current Musicology}

Cohen, Brigid. 2012. "Diasporic Dialogues in Mid-Century New York: Stefan Wolpe, George Russell, Hannah Arendt, and the Historiography of Displacement." Journal of the Society for American Music 6, no. 2: 143-173.

Comini, Alessandra. 1987. The Changing Image of Beethoven: A Study in Mythmaking. New York: Rizzoli International Publications.

de Lerma, Dominique-René. 1990. "Beethoven as a Black Composer." Black Music Research Journal 10, no. 1: 118-122.

DPA (Deutsche Presse-Agentur). 1997. "Gegen Mauricio Kagel: Streit um Erausmuspreis.” Frankfurter Allgemeine Zeitung (print), 1 August. 1999. “Mauricio Kagel erhält 11. Prix Maurice Ravel." Frankfurter Allgemeine Zeitung (print), 3 November.

Dennis, David B. 1996. Beethoven in German Politics: 1870-1989. New Haven: Yale University Press.

Fine, Abigail. 2020. “Beethoven's Mask and the Physiognomy of Late Style.” $19^{\text {th }}$ Century Music 43, no. 3: 143-169.

Goehr, Lydia. 1992. The Imaginary Museum of Musical Works: An Essay in the Philosophy of Music. Oxford: Clarendon Press, rev. 2002.

Heile, Björn. 2006. The Music of Mauricio Kagel. Burlington, VT: Ashgate Publishing Company.

Henken, John. 1988. “Music: A Scaled-Down CalArts Festival.” Los Angeles Times (print). 20 March.

Holtsträter, Knut. 2010. Mauricio Kagel's musikalisches Werk: Der Komponist als Erzähler, Medienarrangeur und Sammler. Cologne: Böhlau Verlag.

Honeck, Mischa, Martin Klimke, and Anne Kuhlmann, eds. 2013. Germany and the Black Diaspora: Ports of Contact, 1250-1914. New York: Berghahn Books.

Horkheimer, Max and Theodor W. Adorno. 1947. Dialektik der Aufklärung: Philosophische Fragmente. Amsterdam: Querido.

Kagel, Mauricio. 1969. Ludwig van: Hommage von Beethoven. Vienna: Universal Edition. 2006. Ludwig van: Ein Bericht. Vienna: Universal Edition.

"Kagel trompe la mort." 1991. Le Monde (print), 12 March.

Kaiser, Joachim. 1970. “Kagels 'Ludwig van...' wird Karajan gemeldet!” Süddeutsche Zeitung (print). 2 June.

Lennox, Sara, ed. 2016. Remapping Black Germany: New Perspectives on Afro-German History, Politics, and Culture. Amherst: University of Massachusetts Press.

Lewy, Guenter. 2017. Perpetrators: The World of the Holocaust Killers. New York: Oxford University Press.

Lockwood, Lewis. 2003. Beethoven: The Music and the Life. New York: Norton.

2013. Beethoven: Studies in the Creative Processes. Cambridge, MA: Harvard University Press.

2020. Beethoven's Lives: The Biographical Tradition. Melton: Boydell \& Brewer.

Mazón, Patricia and Reinhild Steingröver, eds. 2005. Not so Plain as Black and White: AfroGerman Culture and History, 1890-2000. Rochester: University of Rochester Press.

Moore, Andrea. 2019. "Commentary: Beethoven was born 250 years ago. To celebrate, how about we ban his music for a year?” The Chicago Tribune, 30 December. 
https://www.chicagotribune.com/opinion/commentary/ct-opinion-ban-beethovenanniversary-20191230-ukklfgb25baaxcjjiddm3ud76y-story.html.

Olick, Jeffrey K. and Deniel Levy. 1997. "Collective Memory and Cultural Constraint:

Holocaust Myth and Rationality in German Politics." American Sociological Review 62, no. 6: 921-936.

Rehding, Alexander. 2009. Music and Monumentality: Commemoration and Wonderment in Nineteenth Century Germany. New York: Oxford University Press.

Reufsteck, Michael and Stefan Niggemeier, eds. 2005. Das Fernsehlexikon: Alles über 7000 Sendungen von Ally McBeal bis zur ZDF-Hitparade. Munich: Wilhelm Goldmann Verlag.

Richmond Pollock, Emily. 2019. Opera After the Zero Hour: The Problem of Tradition and the Possibility of Renewal in Postwar West Germany. New York: Oxford University Press.

Riezler, Walter. 1944. Beethoven. Zurich: Atlantis Verlag. 6th ed. First published 1936. 1938. Beethoven. Trans. G.D.H. Pidcock. London: M.C. Forrester.

Sayers, W. C. Berwick. 1915. Samuel Coleridge-Taylor, Musician: His Life and Letters. Chicago: Afro-Am Press, (reprint 1969).

Schreiber, Marion. 1969. “Geborene Keverich.” Die Zeit (print), 7 February.

Solomon, Maynard. 1977. Beethoven. New York: Schirmer Books.

Spiel, Hilde. 1970. "Kagels Anti-Beethoven-Film in Wien uraufgeführt." Frankfurter Allgemeine Zeitung (print), 30 May.

Stahl, Christina M. 2009. Was die Mode streng geteilt?! Beethovens Neunte während der deutschen Teilung. Mainz: Schott.

Thurman, Kira. 2020. Twitter post. June 18, 1:04 p.m., https://twitter.com/kira_thurman/status/1273662957579272193.

. 2019. "Performing Lieder, Hearing Race: Debating Blackness, Whiteness, and German Identity in Interwar Central Europe." Journal of the American Musicological Society 72, no. 3: 825-865.

Tommasini, Anthony. 2000. "Music Review: The Show Will Go On, In Spite of Kidnappers." The New York Times (print), 22 November.

Verheyen, Nina. 2010. Diskussionslust: Eine Kulturgeschichte des "besseren Arguments" in Westdeutschland. Göttingen: Vandenhoeck and Ruprecht.

Wendland, Ulrike. 1999. Biographisches Handbuch deutschsprachiger Kunsthistoriker im Exil: Leben und Werk der unter dem Nationalsozialismus verfolgten und vertriebenen Wissenschaftler. Munich: K.G. Sauer.

Wieser, Harald. 1987. “Tod eines Pianisten.” Der Spiegel (print), 14 December.

Wright, Josephine R. B. 1980. "George Polgreen Bridgetower: An African Prodigy in England 1789-99.” The Musical Quarterly 66, no. 1: 65-82.

Zander-Spahn, Brigitte. 1969. “War Beethoven Mischling?” Süddeutsche Zeitung (print), 17 February. 